\title{
VITAMIN D EFFECTS ON LIPID PROFILE AND URIC ACID LEVELS IN THE EXPERIMENTAL MODEL OF METABOLIC DISORDERS IN FRUCTOSE FED WISTAR RATS
}

\author{
LILIA PASHOVA-STOYANOVA ${ }^{1} *$, ANNA TOLEKOVA ${ }^{1}$, MARIA GANEVA ${ }^{1}$, ZHIVKA $^{2}$ \\ TSOKEVA $^{1}{ }^{1}$, PETYA HADZHIBOZHEVA ${ }^{1}$, TSVETELIN GEORGIEV ${ }^{1}$, KRASIMIRA NANCHEVA $^{2}$ \\ ${ }^{I}$ Department of Physiology, Pathophysiology and Pharmacology, Faculty of Medicine, Trakia University, Stara Zagora, Bulgaria \\ ${ }^{2}$ Department of Internal Medicine and Clinical Laboratory, University Hospital "Prof. Dr. Stoyan Kirkovich", Stara Zagora \\ 6000 , Bulgaria
}

*corresponding author: lils@gbg.bg

Manuscript received: February 2019

\begin{abstract}
A growing number of studies suggest that hyperuricemia and low vitamin D levels could contribute to the pathogenesis of metabolic disorders and the development of metabolic syndrome and vice versa - the development of metabolic disorders itself could lead to low vitamin D levels and high uric acid levels. The present study aims to investigate the role of vitamin D effects on uric acid levels and lipid profile in the experimental model of metabolic disorders in fructose fed male Wistar rats. In our study we confirmed the protective role of vitamin D and its effects in lowering the elevated uric acid levels. Vitamin D decreases glucose and uric acid concentrations and improves the cardiogenic lipid profile (cholesterol/HDL and LDL/HDL).
\end{abstract}

\section{Rezumat}

Un număr tot mai mare de studii sugerează că hiperuricemia și nivelurile scăzute de vitamina D pot contribui la patogeneza tulburărilor metabolice și la dezvoltarea sindromului metabolic și vice-versa - dezvoltarea tulburărilor metabolice în sine ar putea conduce la niveluri scăzute de vitamina D și niveluri ridicate de acid uric. Studiul de față își propune investigarea rolului efectelor vitaminei D asupra nivelurilor de acid uric şi asupra profilului lipidic într-un model experimental al tulburărilor metabolice la şobolani Wistar. În prezentul studiu a fost confirmat rolul protector al vitaminei D şi efectele acesteia în asupra valorilor crescute de acid uric. Vitamina D scade concentrațiile de glucoză și acid uric şi îmbunătățește profilul lipidelor cardiogene (colesterol/HDL şi LDL/HDL).

Keywords: vitamin D, uric acid, metabolic disorders

\section{Introduction}

Vitamin D is among the most important factors for having proper calcium metabolism and healthy bones. Growing evidence in recent years links vitamin D with the regulation of the immune function, cell proliferation, differentiation and apoptosis [1, 3]. Nutrition and sun exposure are the main sources of vitamin D. After accumulation, it undergoes hydroxylation first in the liver to produce 25-hidroxicolecalciferol $(25(\mathrm{OH})$ vitamin $\mathrm{D})$ (first stage) and then (second stage) in the kidneys with the help of the enzyme 1 alpha hydroxylase it is converted to its active form, which is 1,25-dihidroxicolecalciferol $(1,25(\mathrm{OH}) 2$ vitamin D) $[24,25]$. Vitamin D deficiency may lead to various health issues that include but are not limited only to bone damage such as osteomalacia and rickets, obesity, type 1 and 2 diabetes mellitus, insulin resistance, metabolic disorders as well as cardiovascular disease $[9,11,24]$.

The prevalence of hyperuricemia in the general population has been increasing. As a propagator of inflammation and oxidative stress high uric acid levels are linked with the development and progression of metabolic disorders, insulin resistance, diabetes mellitus, hypertension, renal disease. A key role in the development of hyperuricemia plays the overactivity of the enzyme xanthine oxidase, which catalyses the oxidation of xanthine and hypoxanthine into uric acid $[12,25,26]$.

In recent years, hyperuricemia (high uric acid levels) has been found to independently predict the development of metabolic syndrome, diabetes and their complications [18, 24, 25, 26]. Experimental studies have shown that hyperuricemia may mediate and play role in the development of insulin resistance, fatty liver and dyslipidaemia especially in fructose-dependent models of metabolic disorders [14, 17, 23].

A growing number of studies suggest that hyperuricemia and low vitamin D levels could contribute to the pathogenesis of metabolic disorders and the development of metabolic syndrome and vice versa the development of metabolic disorders itself could lead to low vitamin D levels and high uric acid levels. 
There is growing evidence that vitamin D and uric acid metabolism pathways are related and there is a connection between hyperuricemia and low vitamin D levels [2, 6, 11, 16, 19].

Metabolic disorders such as fatty liver may be strongly affected and even caused by an excessive fructose intake [4].

Fructose-rich diet induces not only hyperuricemia, but also disturbances in glucose metabolism, impaired glucose tolerance and changes in lipid profile. High glucose levels and disturbances in lipid profile (higher cholesterol levels, higher triglycerides, higher LDL levels) promote different metabolic alterations in glucose and lipid metabolism. The supplementation with vitamin D proved to have protective effect on the lipid profile of rats on fructose-rich diet. The effects vary and differ in enhancing the different lipid parameters $[15,22]$.

The present study aims to investigate the effects of vitamin D on the lipid profile and uric acid levels in fructose fed Wistar rats.

\section{Materials and Methods}

\section{Laboratory animals and procedures}

The experiment was carried out according requirements of the institutional and national regulations and European Directive of 22.09.2010 (2010/63/EU) concerning the protection of animals used for scientific and experimental purposes.

The experiment was carried out on a total of 30 adult Wistar male rats that weighed between 190 and 220 grams. During the experiment, the animals were housed in plexiglas cages with sawdust and exposed to a controlled environment. Before and during the experiment, the rats were exposed to a temperature ranging between 18 and $25^{\circ} \mathrm{C}$ as well as a cycle of 12 hours of light and 12 hours of dark time. The animals had free access to standard lab rat chow and tap water at any time they wished to eat or drink.

\section{Study design}

The first week of the experiment served as a habituation period. Afterwards four groups were formed, each with a different diet: Group 1 was the control group (C) with a total of nine test subjects that received only plain tap water; Group 2 was the fructose fed group (F) with a total of nine test subjects that for a 12 week period had access only to drinking water with a $15 \%$ solution of fructose; Group 3 was the Vitamin D group (D) with a total of six test subjects that received plain tap water but were also supplemented with Vitamin D; Group 4 (FD) was with a total of six test subjects that received both drinking water with a $15 \%$ fructose solution as well as vitamin D at the same time.

For the preparation of the fructose solution a total of $150 \mathrm{mg}$ fructose (Totem, Stara Zagora, Bulgaria) was dissolved in $1000 \mathrm{~mL}$ drinking water. The vitamin D dosage that was used throughout the experiment was
500 IU/kg b.w. [18] liquid vitamin D (Merck Serono) which was administered orally three times a week. Due to its small quantity and in order to facilitate its administration to the test subjects, vitamin D was dissolved in olive oil before being given to the test subjects.

The total length of the experiment was 12 weeks. Vitamin D supplementation began one week after the experiment started while the two fructose fed groups (group F and group FD) began receiving intraperitoneally streptozotocin $20 \mathrm{mg} / \mathrm{kg}$ b.w. (Sigma, St. Louis MO, USA) one week after the vitamin D supplementation.

Various morphometric characteristics such as body weight, waist circumference and distance from muzzle to tail as well as the amount of consumed liquid (either plain water or water with a $15 \%$ fructose solution) were measured daily throughout the full length of the experiment.

The diet of the test subjects was standardized throughout the experimental period.

\section{Experimental protocols}

When the experiment ended after 12 weeks, the animals were anesthetized intraperitoneally with pentobarbital sodium $\left(\mathrm{Nembutal}^{\circledR}\right.$ ) $50 \mathrm{mg} / \mathrm{kg}$ b.w.. They were exsanguinated by cardiac puncture after the thoracic cavity of each test subject was opened and blood samples were collected. Fresh blood $(8-10 \mathrm{~mL})$ was collected directly from the heart in EDTA-containers. The blood samples were immediately centrifuged at $4000 \mathrm{x} \mathrm{g}$ at $4^{\circ} \mathrm{C}$ for 10 minutes. The plasma samples were separated and used immediately for assays of glucose, triglycerides (TG), total cholesterol (CHOL), high-density lipoprotein (HDL) cholesterol, low-density lipoprotein (LDL) cholesterol and creatinine.

Chemicals, reagents and drugs

For the preparation of the fructose solution we use $150 \mathrm{mg}$ fructose (Totem, Stara Zagora, Bulgaria) dissolved $1000 \mathrm{~mL}$ drinking water. Streptozotocin (Sigma, St. Louis MO, USA) was dissolved in cold $0.1 \mathrm{M}$ citrate buffer, $\mathrm{pH} 4.5$ and given intraperitoneally once in amounts of $20 \mathrm{mg} / \mathrm{kg}$ b.w.. Liquid vitamin D (Merck Serono) is given in amounts of $500 \mathrm{IU} / \mathrm{kg}$ b.w. orally, three times weekly. In the end of the experimental period the animals were anesthetized with a single dose of pentobarbital sodium (Nembutal ${ }^{\circledR}$ ) $50 \mathrm{mg} / \mathrm{kg}$ b.w. i.p.

Biochemical laboratory analyses

All four groups of test subjects underwent standard laboratory measurement of the levels of triglycerides, cholesterol, high-density lipoprotein (HDL) and lowdensity lipoprotein (LDL). In addition, the levels of fasting serum glucose, creatinine and uric acid were also measured. Glucose, TG, CHOL, HDL cholesterol, LDL cholesterol and creatinine were determined by standard methods using a Mindray BS-300 analyser (Shenzhen Mindray Bio-Medical Electronics Co., Ltd., China). 
Lipid indexes calculation

Then, the ration between LDL cholesterol and HDL cholesterol levels was calculated in order to determine whether it correlates with the development of dyslipidaemia and other health complications as numerous studies suggest [8]. Furthermore, the ratio between the total level of cholesterol and HDL cholesterol levels was also calculated: LDL/HDL ratio, CHOL/HDL ratio.

Statistical analysis

All quantitative data were processed by Statistics for Windows software (Statistica 64 Version 12) and presented as mean $\pm \mathrm{SD}$. The Student's t-test was performed and a p-value less than or equal to 0.05 was considered as statistically significant.

\section{Results and Discussion}

The biochemical analysis revealed changes in the glucose levels, triglycerides, uric acid and lipid profile of the different groups.

The levels of serum glucose were the highest in group $\mathrm{F}$ $(12.59 \pm 0.62 \mathrm{mmol} / \mathrm{l})$ and were statistically significant $(\mathrm{p}<0.05)$ in comparison with all other groups (Figure 1). There were no significant differences ( $\mathrm{p}>$ $0.05)$ between the serum glucose of the other three groups: controls $(9.83 \pm 2.73 \mathrm{mmol} / \mathrm{L})$, group $\mathrm{D}$ $(8.08 \pm 0.34 \mathrm{mmol} / \mathrm{L})$ and group FD $(7.54 \pm 0.43$ $\mathrm{mmol} / \mathrm{L}$ ) (Figure 1).

Regarding the serum triglycerides, both groups on fructose diet (group F and group FD) had significantly higher levels $(2.16 \pm 0.72 \mathrm{mmol} / \mathrm{L}$ and $1.94 \pm 0.58$ $\mathrm{mmol} / \mathrm{L}$, respectively) in comparison with the triglycerides levels of the control group $(0.81 \pm 0.06$ $\mathrm{mmol} / \mathrm{L})$ and group $\mathrm{D}(0.84 \pm 0.10 \mathrm{mmol} / \mathrm{L})$ (Figure 2).

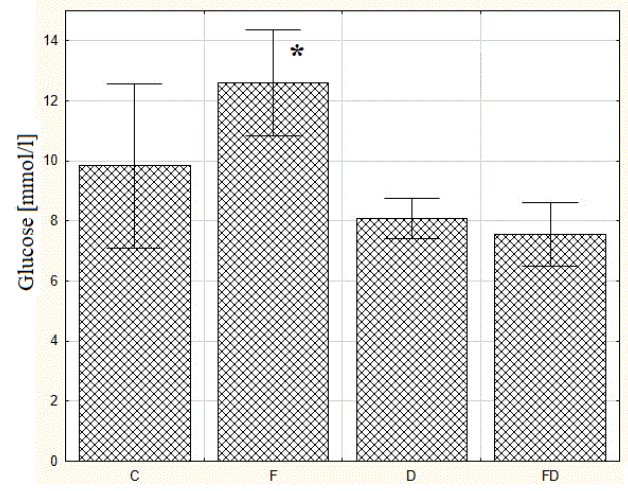

Figure 1.

Changes in glucose levels of male Wistar rats $(\mathrm{C}=$ control group, $\mathrm{F}=$ fructose fed group, $\mathrm{D}=$ group with normal diet supplemented with vitamin $\mathrm{D}, \mathrm{FD}=$ fructose fed group supplemented with vitamin $\mathrm{D}$; * - significant difference between group $\mathrm{F}$ and the other three groups)

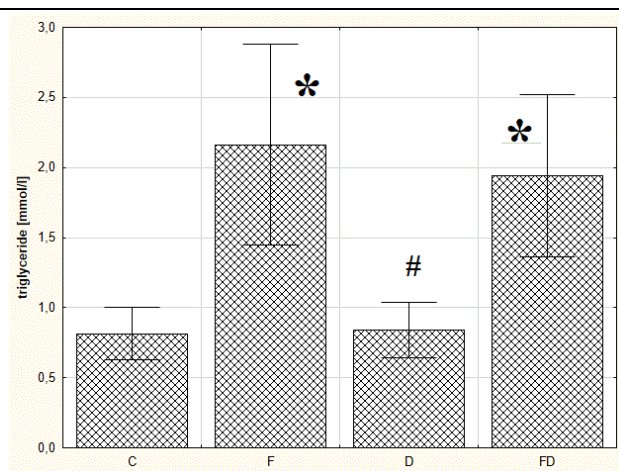

Figure 2.

Changes in triglycerides levels of male Wistar rats $(\mathrm{C}=$ control group, $\mathrm{F}=$ fructose fed group, $\mathrm{D}=$ group with normal diet supplemented with vitamin $\mathrm{D}, \mathrm{FD}=$ fructose fed group supplemented with vitamin $\mathrm{D} ;{ }^{*}$ - significant difference between group F and FD and the control group; \# - significant difference between group F and FD and the group supplemented with vitamin D)

There were no significant differences between the total cholesterol levels of the control and the experimental groups $(p>0.05)$, with the exception of group $D$, which had a significantly lower value $(1.09 \pm 0.20$ $\mathrm{mmol} / \mathrm{L})$ compared with all the other groups $(\mathrm{p}<0.05)$ (Figure 3).

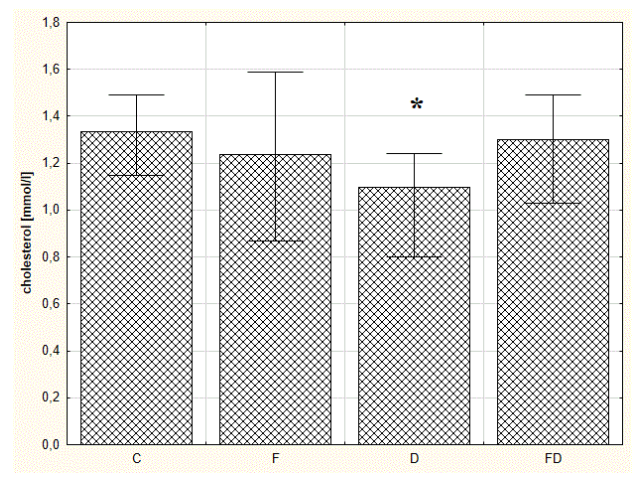

Figure 3.

Changes in total cholesterol of male Wistar rats $(\mathrm{C}=$ control group, $\mathrm{F}=$ fructose fed group, $\mathrm{D}=$ group with normal diet supplemented with vitamin $\mathrm{D}, \mathrm{FD}=$ fructose fed group supplemented with vitamin $\mathrm{D} ;{ }^{*}$ - significant difference between group $\mathrm{D}$ and the other three groups)

Significant differences between the absolute values of LDL and HDL levels were not found (Table I). Similarly, the differences in the creatinine levels of the four groups were small and showed no statistical significance (Table I). However, there were major differences in the atherogenic indexes: cholesterol/ HDL-ratio (Figure 4) and LDL/HDL-ratio (Table I). The differences in the creatinine levels of the four groups vary and have no significant meaning (Table I). Interestingly the control group registered the lowest levels $(51.22 \pm 5.54 \mu \mathrm{mol} / \mathrm{L})$ and the fructose fed group supplemented with vitamin $\mathrm{D}$ the highest levels of creatinine $(68.33 \pm 7.92 \mu \mathrm{mol} / \mathrm{L})$. 


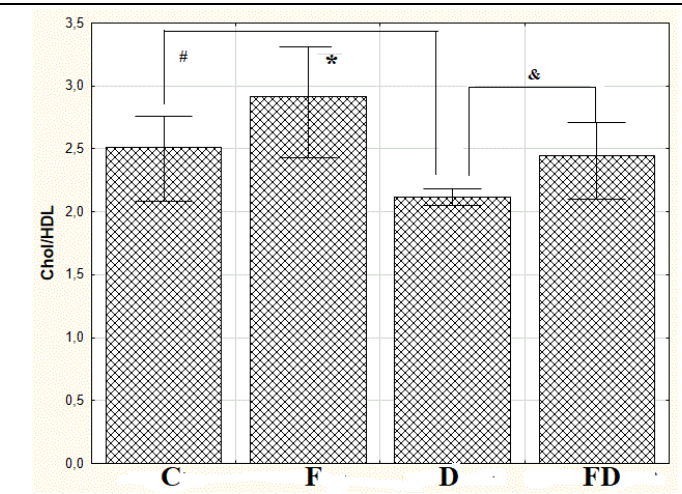

Figure 4.

Changes in one of the main atherogenic indexes - ratio between total cholesterol levels and high-density lipoprotein cholesterol levels of male Wistar rats $(\mathrm{C}=$ control group, $\mathrm{F}=$ fructose fed group, $\mathrm{D}=$ group with normal diet supplemented with vitamin $\mathrm{D}, \mathrm{FD}=$ fructose fed group supplemented with vitamin D; \# - significant difference between group $\mathrm{C}$ and group $\mathrm{D} ;{ }^{*}$ - significant difference between group $\mathrm{F}$ and the other three groups; $\&$ - significant difference between D and FD groups)
The uric acid levels of group F $(86.62 \pm 4.10 \mu \mathrm{mol} / \mathrm{L})$ and control group $(74.57 \pm 7.70 \mu \mathrm{mol} / \mathrm{L})$ were not statistically significant $(\mathrm{p}>0.05)$. The group $\mathrm{D}$ and group FD had lower uric acid levels $(24.00 \pm 2.16$ $\mu \mathrm{mol} / \mathrm{L}$ and $53.00 \pm 4.67 \mu \mathrm{mol} / \mathrm{L}$, respectively) and showed a significant difference $(\mathrm{p}<0.05)$ both with each other and with groups $\mathrm{C}$ and D (Figure 5).

The effects of vitamin D are significant and clearly visible in uric acid levels and blood glucose levels. Group F and group FD both received streptozotocin to accelerate the metabolic disorders and induce diabetes, but because of the protective effect of vitamin $\mathrm{D}$ on the glucose levels group FD is with lower glucose levels than group $\mathrm{F}$ (which is with the highest glucose levels). Vitamin D decreases uric acid and glucose concentrations. The effect of vitamin D on the lipid profile is not clearly defined, because vitamin D causes no significant changes in the absolute values of cholesterol and triglycerides concentrations, but leads to the improvement of the cardiogenic lipid indexes as LDL/HDL and cholesterol/HDL.

Table I

Differences in lipid profile of the experimental groups

\begin{tabular}{ccccc}
\hline GROUP & $\begin{array}{c}\text { LDL } \\
(\mathbf{m m o l} / \mathbf{L})\end{array}$ & $\begin{array}{c}\text { HDL } \\
(\mathbf{m m o l} / \mathbf{L})\end{array}$ & LDL/HDL & $\begin{array}{c}\text { Cr } \\
(\boldsymbol{\mu m o l} / \mathbf{L})\end{array}$ \\
\hline C & $0.43 \pm 0.11$ & $0.54 \pm 0.07$ & $0.82 \pm 0.23$ & $51.22 \pm 5.54$ \\
F & $0.28 \pm 0.13$ & $0.43 \pm 0.11$ & $0.74 \pm 0.50$ & $66.25 \pm 6.23$ \\
$\mathbf{D}$ & $0.28 \pm 0.09$ & $0.52 \pm 0.09$ & $0.54 \pm 0.12$ & $59.00 \pm 8.29$ \\
FD & $0.27 \pm 0.04$ & $0.53 \pm 0.07$ & $0.52 \pm 0.11$ & $68.33 \pm 7.92$ \\
\hline
\end{tabular}

$\mathrm{C}=$ control group, $\mathrm{F}=$ fructose fed group, $\mathrm{D}=$ group with normal diet supplemented with vitamin $\mathrm{D}, \mathrm{FD}=$ fructose fed group supplemented with vitamin D) - LDL = low-density lipoprotein cholesterol, HDL = high-density lipoprotein cholesterol, LDL/HDL - ratio between lowdensity lipoprotein cholesterol and high-density lipoprotein cholesterol, $\mathrm{Cr}$ - creatinine levels

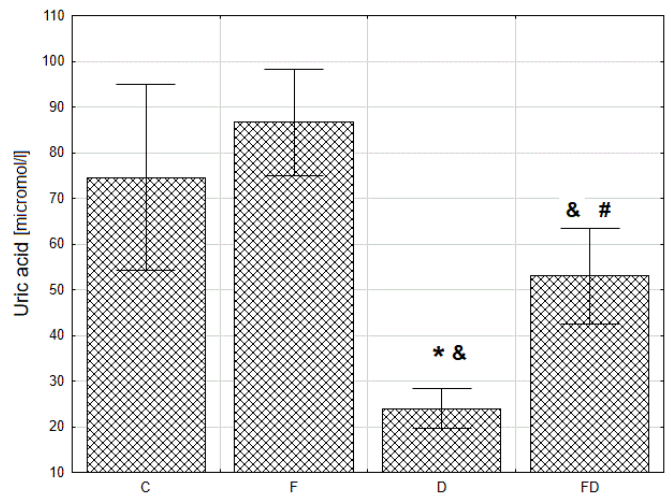

Figure 5.

Changes in uric acid levels of male Wistar rats $(\mathrm{C}=$ control group, $\mathrm{F}=$ fructose fed group, $\mathrm{D}=$ group with normal diet supplemented with vitamin $\mathrm{D}, \mathrm{FD}=$ fructose fed group supplemented with vitamin $\mathrm{D} ;^{*}$ - significant difference between group $\mathrm{C}$ and group $\mathrm{D} ; \boldsymbol{\&}$ - significant difference between D and FD and the fructose fed group;

\# - significant difference between D and FD groups)

The present study explored the relationship between vitamin D supplementation and its effect on blood glucose levels, uric acid levels and changes in the lipid profile. We confirmed the protective role of this vitamin on these biochemical parameters in the experimental model of metabolic disorders in male Wistar rats. Our results are consistent with the findings of some previous studies in this area, which revealed a positive connection between vitamin $D$ supplementation and the improvement of the lipid parameters, glucose and uric acid levels [15, 22].

The significant difference in glucose levels of the groups supplemented with vitamin $\mathrm{D}$, confirmed the protective role of the vitamin in the development of insulin resistance. Fructose-rich diet in combination with streptozotocin leads to acceleration of the metabolic changes and has a great impact of the serum glucose levels (in the long term this kind of changes in the diet and use of streptozotocin lead to insulin resistance and diabetes mellitus) [21]. Our findings confirm this because of the highest glucose levels in the fructose-fed group. Vitamin D has a direct positive impact on glucose levels. It has been found that vitamin D exerts therapeutic effects on obesityassociated insulin resistance and dyslipidaemia through its potent anti-inflammatory activity. Many epidemiological studies indicate that vitamin D deficiency is a potential contributor to insulin resistance and obesity [11]. It seems that vitamin D affects the 
glucose - induced insulin response by both direct and indirect manners. The direct pathways effects are mediated by binding of $1,25(\mathrm{OH}) 2 \mathrm{D}$ to beta cell vitamin $\mathrm{D}$ receptors or within beta cell by 1 alpha hydroxylase. The indirect effects seem to be related to calcium flux to beta cells. Vitamin D may also directly stimulate the insulin responsiveness by increasing the expression of insulin receptors and by regulating the free fatty acid metabolism [1].

The effect of vitamin D on the lipid profile was not clearly defined, as vitamin D did not cause a significant change in the absolute values of HDL, LDL and triglycerides concentrations. Although there were no significant differences in the absolute levels of those parameters, there was observed a great improvement in some of the atherogenic indexes (cholesterol/HDL and LDL/HDL - ratio) and total cholesterol levels. This shows the complicated connections in the body and indicates the protective role of vitamin D for the improvement of the lipid profile and lowering the risk of metabolic disorders due changes in the lipid parameters. It is also assumed that the protective effect of vitamin D on lipid profile might increase with underlying abnormal lipid metabolism or metabolic disorders [20].

The high uric acid levels in the fructose fed group confirmed the importance of this parameter for the diagnosis of metabolic syndrome. It is well known that hyperuricemia has a significant role in fructoseinduced metabolic disorders in animal models and is often associated with diet-induced obesity, high glucose levels and imbalances in the lipid profile [2]. High uric acid levels have pro-oxidant effects and may induce endothelial dysfunction and inflammation by lowering the NO availability, thus promoting the development of metabolic disorders and metabolic syndrome, hypertension, renal and cardiovascular diseases $[2,5,7,13]$. There is an interesting double correlation: insulin resistance may induce a decreased renal excretion of uric acid; the increased uric acid production in turn, may lead to worsening of the insulin resistance by limiting the bioavailability of nitrogen oxide, which is required for insulin-dependent glucose uptake. Insulin resistance favours the uptake of glucose by non-insulin dependent tissues and the polyol pathway that induces the consumption of nicotinamide adenine dinucleotide phosphate (NADPH). The lack of this mediator results in a decreased availability of reduced glutathione with consequent oxidative stress that, in turn, impairs NO production [2].

The meaningful difference in the uric acid levels between the D and FD groups and the other ones, suggests an effect of vitamin D in lowering the uric acid levels and improving the values in the case of hyperuricemia. The idea for a possible direct connection between uric acid and vitamin $\mathrm{D}$ metabolism has been initially raised more than 20 years ago. Nowadays, there is growing experimental evidence confirming that serum uric acid can suppress 1 alpha hydroxylase, the enzyme that is needed to convert $25(\mathrm{OH}) \mathrm{D}$ to its active form $-1,25(\mathrm{OH}) 2 \mathrm{D}$. It is shown that in rats hyperuricemia suppressed 1 alpha hydroxylase leading to lower $1,25(\mathrm{OH}) 2 \mathrm{D}$ and the underlying mechanism of this interaction seems to be mediated by the NFkB pathway [24, 25].

Xanthine oxidase and its overactivity play an important role in the development of hyperuricemia. By applying multi-spectroscopic techniques and dynamic docking simulation, it was confirmed that vitamin D bounds to xanthine oxidase by forming a complex and causes a competitive inhibition of the enzyme, along with inducing constructive changes in the secondary and tertiary structures of xanthine oxidase. This in turn hindered the binding of substrate xanthine and caused the inhibition of xanthine oxidase.

Vitamin D competitively inhibits xanthine oxidase by inserting into the active cavity of the enzyme interacting with surrounding amino acids residues through hydrogen bond and van der Waals forces [16]. Based on these findings, we could assume that the lower uric acid levels in vitamin D treated animals are due to the interaction of this vitamin with the enzyme xanthine oxidase.

In summary, vitamin D supplementation beneficially affected the increased uric acid levels of the fructose fed rats. It additionally had a positive impact on many other parameters like glucose levels, triglycerides and some atherogenic indexes, which indicates a possible prevention of cardiovascular complications.

\section{Conclusions}

In conclusion, our study showed that vitamin D can improve the metabolic disorders induced by high fructose intake and decrease cardiovascular risk. Therefore, vitamin D could be a possible therapeutic option for prevention of such metabolic disturbances, and hyperuricemia and hyperglycaemia in particular.

\section{Conflict of Interest}

The authors declare no conflict of interest.

\section{Acknowledgement}

This study is supported by Grant 9/2016 from Trakia University, Stara Zagora, Bulgaria.

\section{References}

1. Atalay E, Korlaelçi F, Gürsoy G, Karabağ Y, Yildiz M, Erdoğdu HI, Kivrak Y, The possible effect of vitamin $\mathrm{D}$ on uric acid levels in diabetic patients. World Clin J Med Sci., 2017; 1(2): 77-83.

2. Battelli MG, Bortolotti M, Polito L, Bolognesi A, The role of xanthine oxidoreductase and uric acid 
in metabolic syndrome. BBA - Molecular Basis of Disease, 2018; 1864: 2557-2565.

3. Basit S, Vitamin D in health and disease: a literature review. Br J Biomed Sci., 2013; 70: 161-172.

4. Bekyarova G, Tzaneva M, Bratoeva K, Kotzev I, Radanova M, Heme-oxygenase-1 upregulation by $\mathrm{S}$-adenosylmethionine. Potential protection against non-alcoholic fatty liver induced by high fructose diet. Farmacia, 2017; 65(2): 262-267.

5. Cameron AJ, Shaw JE, Zimmet PZ, The metabolic syndrome: prevalence in worldwide populations. Endocrin Metab Clin North Am., 2004;33(2): 351-375.

6. Chen W, Roncal-Jimenez C, Lanaspa M, Gerard S, Chonchol M, Johnson RJ, Jalal D, Uric acid suppresses 1 alpha hydroxylase in vitro and in vivo. Metabolism, 2014; 63(1): 150-160.

7. Eckel RH, Grundy SM, Zimmet PZ, The metabolic syndrome. Lancet, 2005; 365(9468): 1415-1428.

8. Cai G, Shi G, Xue S, Lu W, The atherogenic index of plasma is a strong and independent predictor for coronary artery disease in the Chinese Han population. Medicine (Baltimore), 2017; 96(37): 1-6.

9. Hoza A, Moldovan C, Fărcaș DM, Pallag A, Nemeth S, Marc F, Comparative study of oral antidiabetic therapy and Insulin therapy on hepatic steatosis in patients with Type 2 diabetes mellitus. Farmacia, 2018; 66(4): 652-657.

10. Hsu CH, Patel SR, Young EW, Vanholder R, Effects of purine derivatives on calcitriol metabolism in rats. Am J Physiol., 1991; 260: F596-601.

11. JinW, Cui B, Li P, Hua F, Lv X, Zhou J, Hu Zh, Zhang $\mathrm{X}, 1$,25-Dihydroxyvitamin D3 protects obese rats from metabolic syndrome via promoting regulatory $\mathrm{T}$ cell-mediated resolution of inflammation. Acta Pharmaceutica Sinica B, 2018; 8(2): 178-187.

12. Kanbay M1, Solak Y, Dogan E, Lanaspa MA, Covic A, Uric acid in hypertension and renal disease: The chicken or the egg?. Blood Purif 2010; 30(4): 288-295.

13. King C, Lanaspa MA, Jensen T, Tolan DR, SánchezLozada LG, Johnson RJ, Uric acid as a cause of the metabolic syndrome, Uric acid in chronic kidney disease. Contrib Nephrol Basel, Karger, 2018; 192: 88-102.

14. Kramer CK1, von Mühlen D, Jassal SK, BarrettConnor E, Serum uric acid levels improve prediction of incident type 2 diabetes in individuals with impaired fasting glucose: the Rancho Bernardo Study. Diabetes Care, 2009; 32(7): 1272-1273.

15. Lai I, Sadau Y, Maigari F, Protective effects of calcitriol against fructose-induced hyperglycemia and dyslipidemia in male albino Wistar rats. Am J Res Med Sci., 2018; 3(2): 54-60.
16. Lin S1, Zhang G, Liao Y, Gong D, The inhibitory kinetics and mechanism of dietary vitamins D3 and B2 on xanthine oxidase. Food Funct., 2016; 7(6): 2849-2861.

17. Lv Q, Meng XF, He FF, Chen S, Su H, Xiong J, Gao P, Tian XJ, Liu JS, Zhu ZH, Huang K, Zhang C, High serum uric acid and increased risk of type 2 diabetes: a systemic review and meta-analysis of prospective cohort studies. PLoS One, 2013; 8(2): $1-7$.

18. Mircea C, Cioancă O, Bild V, Iancu C, Stan C, Hăncianu M, In vivo antioxidant properties of some mushroom extracts in experimentally induced diabetes. Farmacia, 2018; 66(2): 257-261.

19. Perez-Pozo SE1, Schold J, Nakagawa T, SánchezLozada LG, Johnson RJ, Lillo JL, Excessive fructose intake induces the features of metabolic syndrome in healthy adult men: role of uric acid in the hypertensive response. Int J Obes (Lond), 2010; 34(3): 454-461.

20. Salum E, Kampus P, Zilmer M, Eha J, Butlin M, Avolio AP, Põdramägi T, Arend A, Aunapuu M, Kals J, Effect of vitamin D on aortic remodelling in streptozotocin-induced diabetes. Cardivasc Diabetol., 2012; 11: 1-8

21. Sharma R, Dave V, Sharma S, Jain P, Yadav S, Experimental models on diabetes: a comprehensive review. IJAPBS, 2013; 4: 01-08.

22. Subih H, Al-Tamimi H, Hamdan H, Bawadi H, Janakat $\mathrm{S}$, Decreased weight gain and enhanced serum biochemical parameters in rats after vitamin $\mathrm{D}$ and $\mathrm{Ca}$ supplementation. Mal J Nutr., 2018; 24(2): 251-256.

23. Takir M, Kostek O, Ozkok A, Elcioglu OC, Bakan A, Erek A, Mutlu HH, Telci O, Semerci A, Odabas AR, Afsar B, Smits G, ALanaspa M, Sharma S, Johnson RJ, Kanbay M, Lowering uric acid with allopurinol improves insulin resistance and systemic inflammation in asymptomatic hyperuricemia. J Investig Med., 2015; 63(8): 924-929.

24. Takir M, Solak Y, Erek A, Köstek O, Oral A, Elçioğlu OC, Bakan A, Afsar B, Özkök A, Jalal D, Johnson RJ, Bahat KA, Odabaş AR, Kanbay M, Association between elevated serum uric acid and vitamin $\mathrm{D}$ insufficiency among the middle-aged and elderly population. Turk J Neph., 2016; 25(2): 182-186.

25. Thakkinstian A, Anothaisintawee T, Chailurkit L, Ratanachaiwong W, Yamwong S, Sritara P, Ongphiphadhanakul B, Potential causal associations between vitamin $\mathrm{D}$ and uric acid: bidirectional mediation analysis. Scientific reports, 2015; 5: 1-8.

26. Vanholder R, Patel S, Hsu CH, Effect of uric acid on plasma levels of $1,25(\mathrm{OH}) 2 \mathrm{D}$ in renal failure. $J$ Am Soc Nephrol., 1993; 4(4): 1035-1038. 